\title{
Thermo-Physical and Mechanical Properties of Al Hashimiyya Basaltic Rocks, Jordan
}

\author{
Sana'a Al-Zyoud \\ Department of Applied Earth and Environmental Sciences, Institute of Earth and Environmental Sciences, Al Al-Bayt University, \\ Mafraq, Jordan \\ Email:alzyoud@aabu.edu.jo
}

How to cite this paper: Al-Zyoud, S. (2019) Thermo-Physical and Mechanical Properties of Al Hashimiyya Basaltic Rocks, Jordan. International Journal of Geosciences, 10, 193-208.

https://doi.org/10.4236/ijg.2019.102012

Received: January 25, 2019

Accepted: February 25, 2019

Published: February 28, 2019

Copyright (c) 2019 by author(s) and Scientific Research Publishing Inc. This work is licensed under the Creative Commons Attribution International License (CC BY 4.0).

http://creativecommons.org/licenses/by/4.0/

\section{Open Access}

\begin{abstract}
Geothermal exploration in northern Jordan is in juvenile phase. North eastern basaltic desert is expected to host, with other rock formations, a shallow geothermal field. For efficient geothermal potential evaluation, a complete understanding of thermo-physical properties of deep reservoir rocks is of utmost importance. Due to the complex technical thermo-physical evaluations of basalts in depth, surficial basalts extending to the west were evaluated. Accordingly, six basaltic sub-flows from Al Hashimiyya were examined into their thermo-physical and mechanical properties. The flows represent the western extinction of large olivine basalt eruption. Different properties were evaluated for oven dried samples: thermal conductivity, permeability, porosity, density and specific heat capacity. In addition, basalts mechanical properties were examined: compressional wave velocity, unconfined compressive strength, indirect tensile strength and point load tests. The results were correlated in proportional patterns. They indicated that thermal conductivity of the studied basalts is dependent on porosity and permeability in parallel with mineral composition. It's found that mechanical properties are controlled by porosity and permeability, too. The studied basalt properties exhibit slight deviation from the continental basalts thermo-physical and mechanical properties reported in the region. Thermal conductivity ranges between 1.89 and $1.32 \mathrm{~W} \cdot \mathrm{m}^{-1} \cdot \mathrm{K}^{-1}$, whereas the porosity and permeability averages at $10.64 \%$ and $9.75899 \mathrm{E}-15 \mathrm{~m}^{2}$, respectively. Additionally, unconfined compressive strength averages at $104.9 \mathrm{Mpa}$ and it's almost 20 times higher than indirect tensile strength which ranges from 8.73 to $2.21 \mathrm{Mpa}$. As the samples were tested under laboratory conditions, in situ conditions will not be reflected by such values. At greater depth, temperature, pressure and hydrothermal activities will certainly affect rock properties. Micro fractures, whether it will be filled or not, will affect basalts properties, too. The results of this work will be used to develop a comprehensive thermo-physico-mechanical
\end{abstract}


model, and improve the ability to predict rock properties at greater depths of Jordanian basalts.

\section{Keywords}

Thermo-Physical Properties, Mechanical Properties, Basalts, Al Hashimiyya, Jordan

\section{Introduction}

Over the last four decades, several investigations on geothermal energy utilizations have been done in Jordan. Most of such studies were accompanied by Natural Resources Authority (NRA) incorporated with different public and private companies and institutions. They deduced that Jordan has wide spread low enthalpy geothermal resources. In Jordan, there are 108 hot springs discharging annually about 25 million cubic meters of thermal water into the Dead Se from lower Cretaceous Sandstone [1]. In addition, various thermal water wells aligned NE Jordan along NW-SE faults. Recorded water temperature ranges from $42^{\circ} \mathrm{C}$ to $50^{\circ} \mathrm{C}$. In this region, thermal wells discharge water from the upper Cretaceous limestone and lower Cretaceous sandstone. Basaltic rocks, the scope of this study, represent the upper unit of aquifer system in NE Jordan. In some areas, geothermal gradient is considered to be high and reaches $50^{\circ} \mathrm{C} / \mathrm{km}$. In central Jordan, the estimated maximum reservoir temperature predicted by geochemical studies is around $115^{\circ} \mathrm{C}[2]$.

Most of the published work gave an attention to the Dead Sea Rift area where more than 50 hot springs were evaluated and considered [3] [4]. Thermal water in north and middle Jordan has been used directly as therapeutic water, e.g. Zara, Zarqa-Ma'in, Afra and North Shunah hot springs of an annual use about $1540 \mathrm{GWh}$ [5] [6]. Other utilizations including bathing and irrigation had earlier been used. It is expected in the near future that shallow geothermal water will have greenhouses heating for flowers planting utilizations. In addition, fish farming is another future application to provide the local market with fresh fish [2]. In addition, [7] proposed a future geothermal utilization for air conditioning and heating of the Queen Alia Airport. On the other hand, [8] deduced that geothermal energy in Jordan could be utilized for electricity generation. Various locations in Jordan are suitable for shallow geothermal storage due to the recorded underground temperature within the upper $100 \mathrm{~m}$ in subsurface. [9] investigated geothermal cooling potential of basaltic reservoir in NE Jordan. The previous studies concluded that the origin of thermal waters in Jordan is of meteoric type, while the source of heat is the deep circulation of cold and hot mixed water. In NE Jordan, geothermal potential for different utilizations is expected. Geothermal resources in this area did not receive detailed investigations. Future exploration in NE Jordan needs further evaluations and assessment of 
this resource.

Correlation between reservoir rocks thermal conductivity and their physical properties had previously been modeled. Numerous models have been developed to determine thermal conductivity based on mineral constituents, density, permeability, porosity, uniaxial compressive strength and $\mathrm{P}$-wave velocity (e.g. [10]-[16]). Nevertheless, some investigations include oceanic basalt thermo-physical properties [17] have been done, such results could not be applied for continental flood basalts in Jordan. Physical properties are highly affecting the heat efficiency in any geothermal reservoir evaluation. Permeability is one of the most important properties which influence thermal conductivity. [18] stated that thermal conductivity and permeability correlation is only feasible where both properties are measured for the same sample; consequently, anisotropic factors should be considered. Comprehensive investigations were reported by [19] for thermal conductivity and permeability interrelation. He specified different factors controlling thermal conductivity and permeability interrelation such like; mineral geometry, crystal size, vesicularity includes vesicles internal geometry and microstructures. [19] investigated mineral crystal size and microstructure for their effect on thermal conductivity and permeability correlation.

[14] presented the data which expected to improve the statistical confidence on geophysical and thermo-hydro-mechanical numeric models data. In addition, he examined the ability to predict rock properties at greater depths of the Taupo Volcanic Zone in New Zealand. Mechanical properties correlation with thermo-physical properties were modeled, too. [20] found that the ratio of secondary minerals to primary minerals (SEC/PR) of the studied ultramafic rocks have a good correlations with their physicochemical and mechanical properties. They suggested that alteration has a negative effect on the engineering performance of the ultramafic rocks. [21] determined thermal conductivity and thermal diffusivity with empirical relations from physical properties of limestone, dolomite, and siliciclastic rock samples. He found that the Grüneisen parameter and melting temperature decrease nonlinearly but the Debye temperature decreases linearly with increasing porosity. In addition, [22] studied the petrophysical properties (density, P- and S-wave velocity, porosity) and ultrasonic P- and S-wave attenuation mechanism for the saturated Deccan basalt cores. They found an interesting relationship between $\mathrm{P}$-wave velocity and porosity.

This study aimed at examines the rock physical properties influence on thermal conductivity. On the other hand, a relationship between examined thermo-physical and mechanical properties will be correlated. This will develop a better understanding of basalts' thermo-physical and mechanical properties interrelations. The properties involved in this work are permeability, porosity, density, compressional wave velocity, point load, indirect tensile strength and unconfined compressive strength parallel with thermal conductivity. The results obtained in this work are expected to develop data confidence on thermo-physical models for the studied rocks. Therefore, it will improve the ability 
to predict basaltic rocks properties from limited input data at greater depths.

\section{Geologic Settings}

Successive basaltic flows were erupted from Cenozoic; Miocene to Pliocene time in the magmatic activity within Arabian plate [23]. This basaltic flood which covers an area of about 12,000 $\mathrm{km}^{2}$ is known as Harrat Al Shaam [24]. The Basaltic rocks in Al Hashimiyya are of Abed Olivine Basalt of Pliocene age [23]. The studied flow is considered as the western extinction of Harrat eruption (Figure 1).

[25] divided Jordanian basalts into six major flows (named B1-B6) and one eruption of tephra (given a name of B't). B1-B3 basaltic flows are not visible in Jordan, but are known from borehole data [26]. [27] proposed a new classification based on K-Ar dating. They divided volcanic rocks into three major episodes: Oligocene to early Miocene (26 - $22 \mathrm{Ma}$ ), middle to late Miocene (13-8 $\mathrm{Ma}$ ), and late Miocene to Pleistocene ( $7 \mathrm{Ma}$ to $<0.1 \mathrm{Ma}$ ) Al Hashimiyya basalts belong to youngest eruption phase with an age of ca. $2 \mathrm{Ma}$ [27]. Basalts of ca. 400 $m$ thickness of successive flows are found in the NE part of the study area, while less than $50 \mathrm{~m}$ is found in the southern parts of the study area [26].

The studied basalts show slight vertical and lateral variations in morphology. Basaltic flows in $\mathrm{Al} \mathrm{Hashimiyya} \mathrm{are} \mathrm{composed} \mathrm{of} \mathrm{a} \mathrm{series} \mathrm{of} \mathrm{gently} \mathrm{dipping} \mathrm{to} \mathrm{sub}$

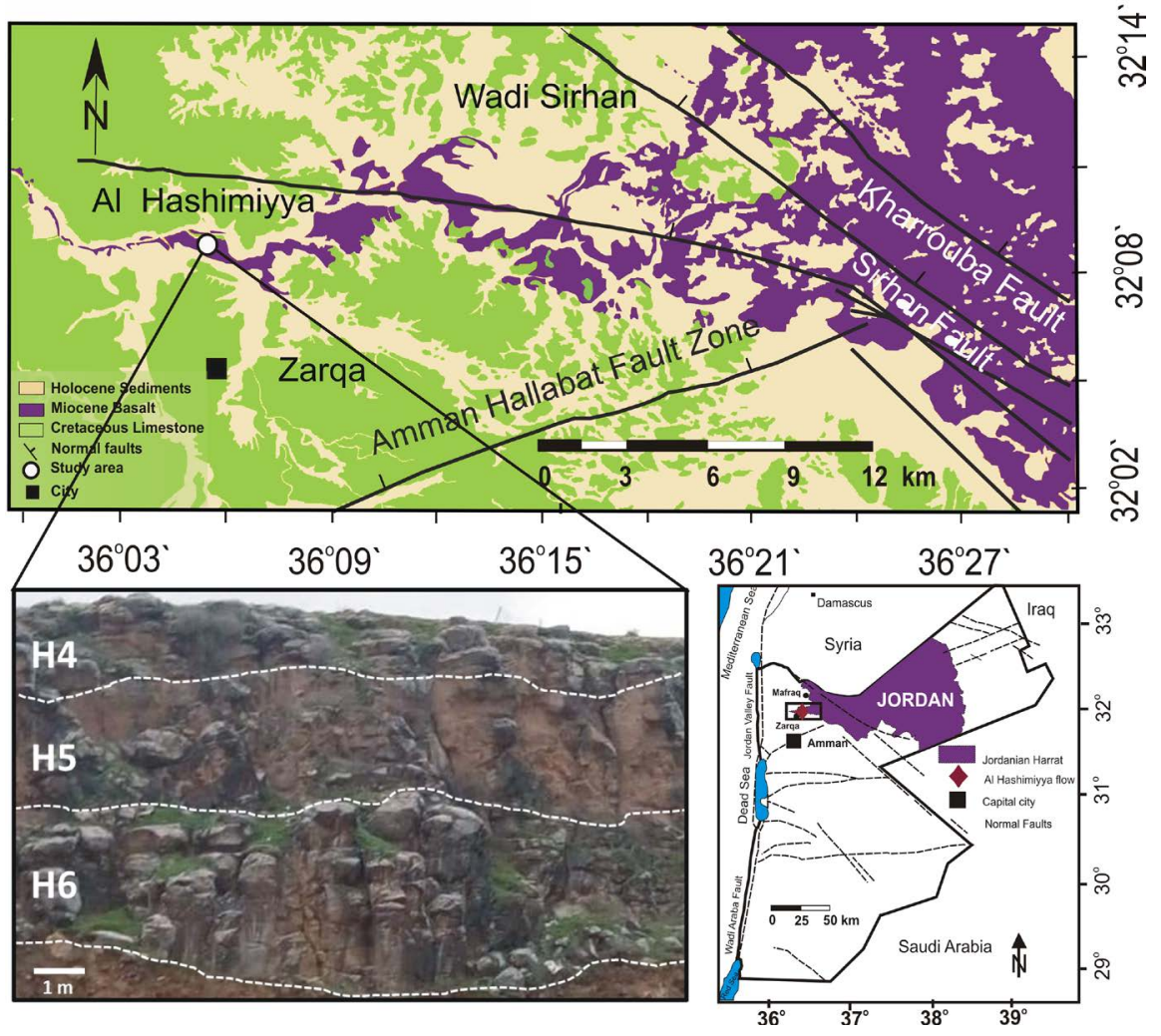

Figure 1. Geologic map of the study area (after [23]). Lower right; location map of the study area, Jordanian Harrat is modified after [24]. Lower left; lower $10 \mathrm{~m}$ of the studied basalt flow (H4 to H6 sub-flows). 
horizontal lava flows. This basalt flow come from Al-Khalidiyya town, locates at south-eastern of Al-Mafraq city, then it extends to fill Wadi Ad Dhulayl through Manshiatt Al-Ulayyan to the west. It crossing Al-Zarqa-Al-Mafraq highway after that it's partitioning into two flows, the northern one ends in Ar Rusaifa ash Shamaliya crossed Al Hijaz Railway. The second flow to the south is passing Al-Kherba as Samra ending south west at Al Hashimiyyia city down (Figure 1). At Wadi Al-Sukhneh the eruption divided into two parts, the highest one shows a step-like structure in Wadi Wad'a. While the lower extends along Wadi Az Zarqa up to city of Jerash (Sarrut village) [28]. Al Hashimiyya studied flow is measured to be around $20 \mathrm{~m}$ thickness. The basalts in the study area are lithologically well differentiated, and structurally developed. It is easy to identify each basalt flow from its special lithology and primary magmatic structures. The study area basalt cover about $30 \mathrm{~km}^{2}$ northern Zarqa city. The studied flow locates at latitude of $32^{\circ} 08^{\prime} 50^{\prime \prime} \mathrm{N}$ and longitude of $36^{\circ} 05^{\prime} 15^{\prime \prime} \mathrm{E}$. Al Hashimiyya flow subdivided into six sub-flows dependence on lithological and structural aspects. The vertical extinction of each sub-flow eruption is indicated by about $30 \mathrm{~cm}$ of vesicular basalt. Al Hashimiyya basalts eruptions form successive sheet-like flows with stepped cliffs.

The basalts erupted in this area parallel to Wadi Sirhan fault system extending NW-SE (Figure 1). Al Hashimiyya flow was selected after taking different determining criteria into concern; 1) location as it's the south western utmost end of basaltic flow in the region, 2) the outcrop accessibility, 3) structural aspects of presenting moderate (upper sub-flows) to low (lower sub-flows) joints and fractures, 4) basalt alteration is uncommon under microscope as in the other flows in the eastern area [16].

The total studied thickness is about $20 \mathrm{~m}$, the bottom sub-flow elevation is 512 $m$ a.s.l. The upper two sub-flows are characterized with humpy ridges structure and hexagonal cooling joints. The blocky structure (of Aa lava type) is exhibited by the middle and the lower sub-flows. In general, Al Hashimiyya flow is characterized by tectonic fractures parallel with the preferred orientation of main fault system of NW-SE direction.

\section{Methodology}

Total $20 \mathrm{~m}$ thickness of basaltic sub- flows was investigated. Two main complementary sections were taken, along the flows with 10 to 14 samples from each sub-flow. The samples were prepared into predefined dimensions or milled for the thermo-physical and mechanical characterization.

Optical Scanning Method was used to measure thermal conductivity [19]. Thermal conductivity was conducted under standard laboratory conditions on oven dried samples. Optical Scanning Method is based on scanning of sample surface (curved or flat) with a straight and constantly run mobile heat source of $4^{\circ} \mathrm{C}$ temperature. This heat source is associated with a temperature sensor. Such device is one of the quick thermal conductivity measuring apparatus. However, 
different sample types can be measured considering thermal conductivity anisotropy. The measuring conception is as follows; a $1 \mathrm{~mm}$ diameter mobile heat source is heating with scanning the examined surface. The sample is few centimeters above the mobile heat source. The accompanied (with fixed distance a part) temperature sensor is moving parallel with the heat source in a constant speed. Sample thermal conductivity is calculated as the arithmetic mean of narrow successive measurements on the sample surface. Before and after heat measurements are controlling the local scanned measurements. On the scan line, two known thermal conductivity standards are located prior and after the sample. The standards have almost the same thermal conductivity $\left(\lambda_{R}\right)$ as the sample. The comparison between the studied sample and the generated temperature differences of the standards will determine the sample thermal conductivity $\lambda$ (Equation (1)) with an accuracy of $3 \%$. The measured electrical potential for both samples $U_{R}$ and $U$ is dependent on the ratio of temperature rise for standard and sample $\Theta_{R}$ and $\Theta$, as described below [19]:

$$
\lambda=\lambda_{R}\left[\frac{\Theta_{R}}{\Theta}\right]=\lambda_{R}\left[\frac{U_{R}}{U}\right]
$$

The heat capacity was calculated out of the thermal conductivity, temperature diffusivity and bulk density. Permeability measurements were carried out using a pressure air driven gas-permeameter. The gas pressure permeameter allows an infinite measurements, this can be allocated to distinct layers of a rock sample. The air is pressed into the sample surface through a vertical detached ram. Compressed air is driven through an outlet to initiate a specific flow-through. This will lead to initiate a volumetric flow rate. Together with the dynamic viscosity and adaptor radius, the permeability is calculated as a result of volumetric flow rate (Equations (2) \& (3)) [29], the error is limited to a maximum deviation of $5 \%$.

$$
q_{i}=\frac{p_{l}}{p_{i}} M_{i}
$$

where $q_{i}$ is the volumetric flow rate, $p_{l}$ is the atmospheric pressure, $p_{i}$ is the injection pressure and $M_{i}$ is the mass flow rate. The permeability $(k)$ is calculated then as follow

$$
k=\frac{q_{i} \eta p_{i}}{r\left(p_{i}^{2}-p_{L}^{2}\right) F_{G}}
$$

where $\eta$ is the dynamic viscosity, $r$ is the adapter radius and $F_{G}$ is a geometric factor.

Porosity was measured using pycnometer. This device measures the porosity considering a known envelope volume, bulk density and the particle density of an examined cylindrical sample. In general, with an accuracy of $0.03 \%$, the device computes both densities by measuring the displacement generated after applying a pressure on the sample including pore volume. This is measured in a cylindrical cell, filled with powder, ends with a mobile ram. The concept of 
measuring is to calculate the difference between two readings; the first is the measured distance that powder needs to reach a predefined pressure and second, is the measured distance needed to reach the previous pressure for both powder and sample together. The pores volume is calculated by integrating the sample oven dry weight with the particle density [30].

Unconfined compression strength $\left(\sigma_{c}\right)$ is the most important strength tests among rock physical properties. The maximum applied uniaxial stress that a rock sample can stand without failure is its uniaxial compressive strength; it is calculated using the following (Equation (4)):

$$
\sigma_{c}=\frac{F_{o}}{A}
$$

where:

$F_{o}=$ The maximum applied load, KN.

$A=$ Area of the specimen cross section, $\mathrm{cm}^{2}$.

For ultrasonic wave velocity measurement, a sample is aligned between two transducers. As the device turned on, wave pulses are transmitted from one transducer to the other through the sample. Travel time of the transmission is given in microseconds, and thus the velocity can be calculated considering the length of the specimen.

One of the basic rock tests which indicates the failure strength is tensile strength test. Before conducting the tensile strength test, basalt specimens were prepared according the (ISRM) standards. The prepared sample was placed between two platens so that its diameter is perpendicular to the platens plane. The load was applied at a rate is of $0.22(\mathrm{KN} / \mathrm{sec})$, until failure was reached. Consequently, cracks starting at this region and propagate along the plane parallel to the direction of load application until the basalt sample split into two parts. The indirect tensile compressive strength $(\sigma)$ can be represented mathematically using the following relationship (Equation (5)):

$$
\sigma=\frac{2 P}{\pi D l}
$$

where:

$$
\begin{aligned}
& P=\text { Maximum load applied, } \mathrm{Kg} . \\
& D=\text { Core diameter }, \mathrm{cm} . \\
& I=\text { Core thickness, } \mathrm{cm} .
\end{aligned}
$$

Point load test is that test examined rock's response on tension stress, thus it belongs to the tensile strength tests family. This test has three variations; diametric, axial or irregular lumps, the choice of which depends on the available specimen geometry [31]. In this test basalt samples were loaded horizontally between two thin ends of the device those are compressed perpendicular to the specimen until fracture occurred. The sample then is split ruptured into four pieces. The load strength index (Is) of the examined basalt was calculated as follows (Equation (6)): 


$$
I s=\frac{P}{D^{2}}
$$

where:

$P=$ failure load, KN.

$D^{2}=$ Core diameter, $\mathrm{cm}$.

\section{Results and Discussion}

Correlation between thermal conductivity, permeability, porosity, thermal diffusivity, density, specific heat capacity, unconfined compressive strength, compressional wave velocity, indirect tensile strength and point load are illustrated in Figure 2. Basalts sub-flows are given names $\mathrm{H} 1$ to $\mathrm{H6}$. Vertical axis in this figure is not to scale. Table 1 gives the ranges and mean values (with standard deviation) of the measured properties. In addition, a statistical Box-Whisker plot of thermo-physical and mechanical properties are shown in Figure 3.

From the results illustrated above it can be concluded that basalts thermal conductivity correlates with several physical properties; thermal diffusivity, specific heat capacity, unconfined compressive strength and point load. In contrast, it's inversely proportioned with permeability, porosity and indirect tensile strength. Density and compressional wave velocity does not show obvious correlation with thermal conductivity. Thermo-physical properties of Al Hashimiyya

Table 1. Mean and ranges; minimum and maximum values of the examined basalts properties.

\begin{tabular}{cccccccccccc}
\hline & $\begin{array}{c}\text { Thermal } \\
\text { Conductivity } \\
\left(\mathrm{W} \cdot \mathrm{m}^{-1} \cdot \mathrm{K}^{-1}\right)\end{array}$ & $\begin{array}{c}\text { Permeability } \\
\left(\mathrm{m}^{2}\right)\end{array}$ & $\begin{array}{c}\text { Porosity } \\
(\%)\end{array}$ & $\begin{array}{c}\text { Thermal } \\
\text { Diffusivity } \\
\left(\mathrm{m}^{2} \cdot \mathrm{s}^{-1}\right)\end{array}$ & $\begin{array}{c}\text { Density } \\
\left(\mathrm{kg} \cdot \mathrm{m}^{-3}\right)\end{array}$ & $\begin{array}{c}\text { Specific } \\
\text { Heat } \\
\text { Capacity } \\
\left(\mathrm{kJ} \cdot \mathrm{kg}^{-1} \cdot \mathrm{K}^{-1}\right)\end{array}$ & $\begin{array}{c}\text { Unconfined } \\
\text { Compressive } \\
\text { Strength } \\
(\mathrm{Mpa})\end{array}$ & $\begin{array}{c}\text { Compressional } \\
\text { Wave Velocity } \\
(\mathrm{km} / \mathrm{s})\end{array}$ & $\begin{array}{c}\text { Tensile } \\
\text { Strength } \\
(\mathrm{Mpa})\end{array}$ & $\begin{array}{c}\text { Point } \\
\text { Load } \\
\left(\mathrm{Mn} / \mathrm{m}^{2}\right)\end{array}$ \\
\hline Mean (SD) & $1.55(0.19)$ & $9.76 \mathrm{E}-15(-)$ & 10.64 & 0.95 & 2.68 & 0.66 & 104.9 & 0.55 & 5.16 & $6.08(0.37)$ \\
Max & 1.89 & $4.79 \mathrm{E}-14$ & 12.76 & 1.09 & 2.73 & 0.93 & 168.7 & 0.57 & 8.73 & 6.63 \\
Min & 1.32 & $2.72 \mathrm{E}-16$ & 7.50 & 0.83 & 2.59 & 0.51 & 41.2 & 0.54 & 2.21 & 5.41 \\
\hline
\end{tabular}

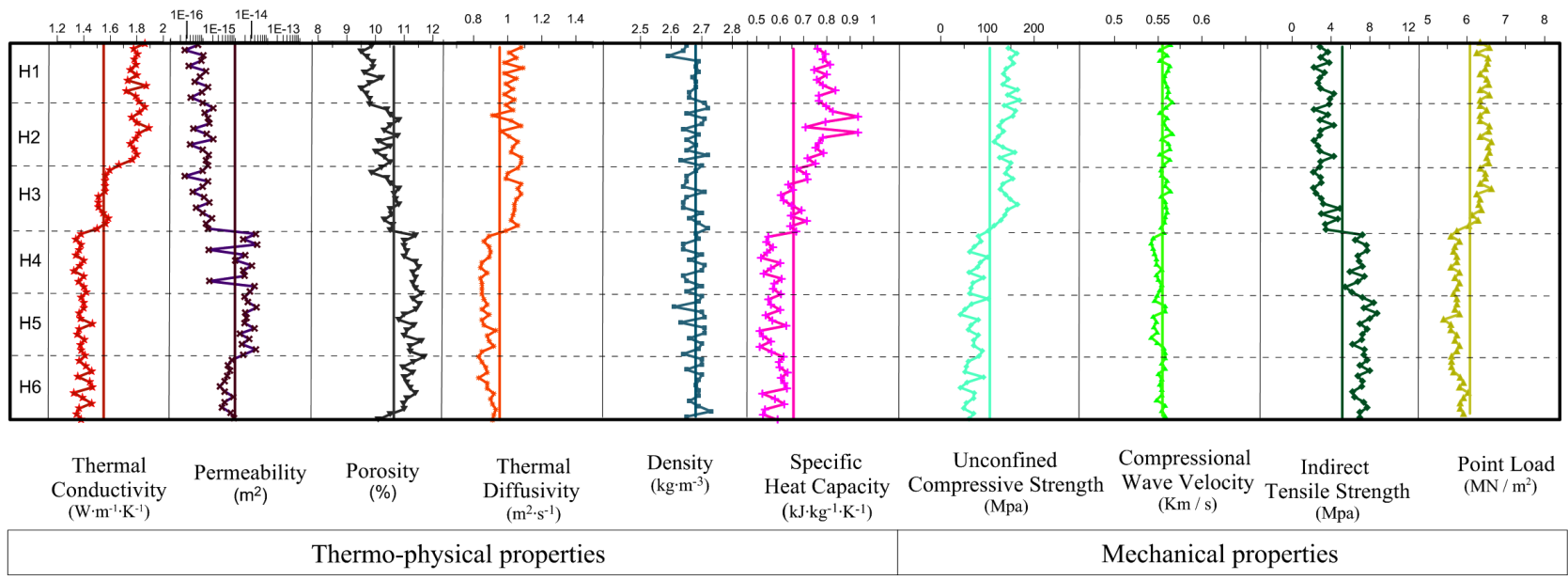

Figure 2. Correlations of thermo-physical and mechanical properties of Al Hashimiyya basalts. 


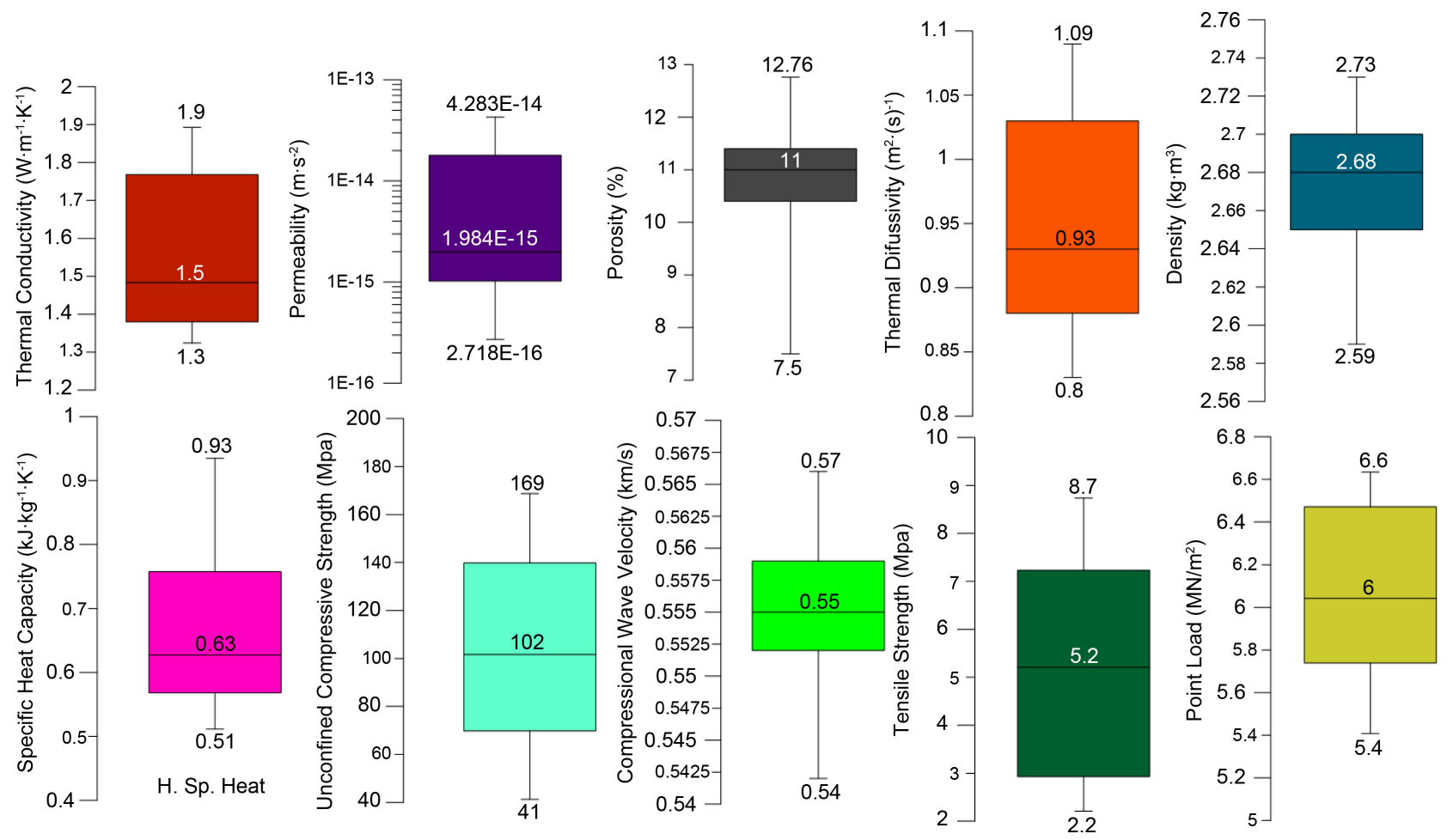

Figure 3. Box-Whisker plots of thermo-physical and mechanical properties of the studied basalts.

basalts are in line with eastern Jordanian Harrat basalt properties reported by [9]. Thermal conductivity is proportionally correlates with some mineral constituents of basalts. A predicting model which link basalt thermal conductivity with its mineral constituents in this area has been approached [16].

Unconfined compression strength is the most important index strength test as well as the most important property needed for rock classification. It's found that average value of unconfined strength at Al-Hashimiyya basalts of 104.9 $\mathrm{MPa}$ is match very well with the value of $105.8 \mathrm{MPa}$ reported by [32] in Northern Jordan basalt. Both values are in the range of continental basalt unconfined compressive strength values reported earlier. On the other hand, most rocks exhibit a weak tension strength value compared with compressive one, this weakness is very important in structure and excavation constructions. Therefore, indirect tensile strength is found to be one fifth of the unconfined compressive strength of Al Hashimiyya basalts. In addition, compressional wave velocity is in the range of basalts reported by [33], which is of $(0.3940-0.5150) \mathrm{km} / \mathrm{s}$. Compressional wave velocity may be attributed to the values of porosity, density of micro fractures, mineral composition and dry density. [34] obtained highly correlated models $\left(\mathrm{R}^{2} 1 / 40.717\right.$ - 0.890$)$ between $\mathrm{P}$-wave velocity and density, porosity, uniaxial compressive strength, Brazilian tensile strength, modulus of elasticity and Poisson's ratio for basaltic rocks in other region. [32] reported that the ultrasonic wave velocity in basalt is $0.5399 \mathrm{~km} / \mathrm{s}$, it's slightly lower than those of Al-Hashimiyya basalt which averages $0.5548 \mathrm{~km} / \mathrm{s}$. However, both readings are within the continental basalt range of ultrasonic wave velocity which is $(0.35$ - 
$0.55) \mathrm{km} / \mathrm{s}$ [33]. Point load strength averages 6.08 Mpa. Relatively, low point load strength values are due to the stress impact distribution over the objected area to the device platens during the test. This test is conducted on un-prepared ends cores, where the diameter is the most important parameter in determining the point load strength.

A number of factors may affect the results; rock weathering degree, micro fractures and porosity. In addition, other factors, such as moisture content, sample surface flatness, loading rate, specimen dimensions and surface shape, might have also great impact on the results. In addition, for aggregates' mechanical and physical properties are affected by texture, size, shape, chemical, and mineralogical compositions ([35] [36] [37]).

Thermo-physical and mechanical rock properties were determined at oven dried samples with an ambient temperature and pressure. This will enable a direct comparison of all examined rock samples. The actual conditions on depth do not reflected by the laboratory conditions. Deep conditions include; higher pressure, higher temperature, water saturation, steam with other gases contents and surrounding hydrochemistry. In compare, higher temperatures at depths, parallel with increasing pressure, may change the values of porosity, permeability, unconfined compressive strength, indirect tensile strength and point load strength from the laboratory measurements. This effect is caused by the development of micro fractures at higher depths. Rock thermal expansion, parallel with pressure effect, will form micro and macro cracking. This will develop a second porosity, increasing the total porosity value. In addition, permeability is expected to be increased, too. In contrast, rock strength may be reduced, as well ([38] [39] [40] [41] [42]). The effect of such cracks on density, heat and compressional wave velocity is less noticeable in saturated rocks. This is probably caused by contact resistance reduction by the fluids [14]. [43] and [44] stated that if the porosity is increased by a factor of 3 to 4 then the strength will be decreased by a factor of 8 . If this pores and cracks getting saturated with water then the thermal conductivity and compressional wave propagation are expected to be increased as water conduction is higher than air.

Basalt rocks, as a crystalline igneous rock, have tightly interlocked crystals which affect heat and compressional waves. This can be seen obviously comparing with other rock types [14]. However, the increasing in grains contact resistance between mineral constituents may decrease heat and ultrasonic wave propagation by up to $50 \%$. Consequently, heat and compressional wave conduction is expected to duplicate in saturated porous reservoir rocks ([41] [42] [45] [46] [47]).

However, studies on thermo-physical rock properties evaluations under high pressure, temperature and fluid saturation are very rare, due to the technical effort needed. According to [48] and [49], the existing apparatus are typically capable of reaching sufficient pressure conditions, but the maximum temperature is often limited by $200^{\circ} \mathrm{C}$, and only selected rock properties such as permeability, 
acoustic velocity and rock strength can be measured.

In addition to temperature, pressure and water saturation, the scale dependence limitations affect results, too. Laboratory measurements will considerably differs from in situ reservoir measurements due to the small size and relative homogeneity of the examined small samples. In-situ measurements cover a much larger volume of heterogeneous rocks [45].

Furthermore, geothermal systems may modify reservoir rocks properties due to the continuous physical and chemical condition changes. Hydrothermal alteration, as an example, can either increase thermal conductivity, wave velocity, permeability and rock strength by precipitates secondary minerals in pores and fractures, or, decrease them by dissolving the primary mineral constituents leaving cavities filled with new different secondary minerals. In depth, it's expected for the basalts porosity and permeability to be increased by micro and macro fractures. However, hydrothermal alteration may seal those cracks and reduce their effect on thermo-physical and mechanical properties. Porosity and fluid saturation will control thermo-physical properties of basalts, too. This is because of relatively high porosity exhibited by the examined basalts flows ([13] [43] [44] [50] [51]). [52] discussed the saturation effects on thermal properties. They found that thermal conductivity and thermal diffusion coefficient of rocks increases under water saturated conditions compared to dry conditions, but the specific heat capacity decreases. In addition, [53] indicated that the rock lithology is the predominant control on the physical and mechanical properties of the geotechnical units. They suggested that this correlation is due to mineral precipitation within fractures and pores in the brecciated lava margins. They concluded that permeability of the unaltered breccia facilitated efficient hydrothermal fluid circulation and mineral precipitation.

Therefore, thermo-physical and mechanical rock properties changes with depth are expected to be highly variable. Hence, predicting physical and mechanical properties of reservoir rocks at depth become very complicated and un applicable, only estimations can be done.

\section{Conclusions}

This work examined thermo-physical and mechanical rock properties evaluation of basaltic rocks in Al Hashimiyya area. Samples covered about $20 \mathrm{~m}$ thickness of six successive sub-flows. This study provides the most comprehensive thermo-physical and mechanical properties data suite on the Jordanian Harrat basaltic rock to date. Previous work investigated some of the properties separately. Thus, such developed correlations between thermal conductivity and other rock properties provide a unique and new reference data set for less studied thermo-physical basalt properties in Al Hashimiyya. The results outlined in this work are expected to develop a new approach for predicting rock properties into a pre-defined thermo-physical model. Such models may be expanded when the input data are limited, due to depth conditions, based on different patterns of 
correlations given in this work.

Study outcomes reveal that thermo-physical and mechanical properties of Al Hashimiyya basalts are of regional ranges of continental basalts. Al Hashimiyya basalts thermal conductivity averages at $1.55 \mathrm{~W} \cdot \mathrm{m}^{-1} \cdot \mathrm{K}^{-1}$. Porosity ranges between $12.76 \%$ and $7.5 \%$. The basalts density in the study area averages $2.68 \mathrm{~kg} \cdot \mathrm{m}^{-3}$. The indirect tensile strength averages $5.16 \mathrm{Mpa}$ and is one fifth the unconfined compressive strength which ranges from 168.7 to $41.2 \mathrm{Mpa}$.

The results indicated that thermal conductivity is proportionally correlated with thermal diffusivity, specific heat, unconfined compressive strength and point load. While other properties like permeability, porosity and indirect tensile strength show an inverse proportion with thermal conductivity. Density and compressional wave velocity does not exhibit a direct correlation with thermal conductivity. Different factors, which affect the results in laboratory and depth, had been discussed. Permeability and porosity are expected to be the most controlling factors on thermal conductivity results. They also affect other mechanical properties of basalts. In addition, temperature, pressure, fluid saturation and hydrothermal solutions are expected to change the results values in depth.In depth, in addition to the microcracks, the relative heterogeneity in pores shape, volume and distribution of basaltic sub-flows would absolutely affect the rock properties. Hydrothermal solutions will definitely change pores and fractures effects in two different ways: cavities improvement or existing pores and cracks filling. Therefore, reservoir conditions will limit the ability to predict thermophysical and mechanical properties in depth.

\section{Conflicts of Interest}

The authors declare no conflicts of interest regarding the publication of this paper.

\section{References}

[1] Kabariti, M. (2005) Identification of National Energy Policies and Energy Access in Jordan, Amman. National Energy Research Center/Energy Research Group/Report, $52 \mathrm{p}$.

[2] Saudi, A. and Swarieh, A. (2015) Proceedings World Geothermal Congress 2015 Melbourne, Australia, 19-25 April 2015. Geothermal Energy Resources in Jordan, Country Update Paper.

[3] Sunna, B. (2004) Recommended Approaches to Develop the Direct Utilization of the Geothermal Energy (Hot Water) in Jordan. International Water Demand Management Conference, Amman.

[4] Schäffer, R. and Sass, I. (2014) The Thermal Springs of Jordan. Environmental Earth Sciences, 72, 171-187. https://doi.org/10.1007/s12665-013-2944-4

[5] Al-Dabbas, M. (2011) Achievement of Geothermal Energy Using Ground Heat Exchanger in Ma'in. Journal of Mechanical Science and Technology, 25, 2013-2023. https://doi.org/10.1007/s12206-011-0520-y

[6] International Geothermal Association, IGA. (2012) https://www.geothermal-energy.org/explore/our-databases/geothermal-power-data 
base/\#direct-uses-by-purpose

[7] Swarieh, A. (2008) Geothermal Water in Jordan. United Nation University-Geothermal Training Programme, Tianjin.

[8] Abu-Hamatteh, Z., Al-Zughoul, K. and Al-Jufout, S. (2011) Potential Geothermal Energy Utilization in Jordan: Possible Electrical Power Generation. The International Journal of Thermal \& Environmental Engineering, 3, 9-14. https://doi.org/10.5383/ijtee.03.01.002

[9] Al-Zyoud, S. (2012) Geothermal Cooling in Arid Regions: An Investigation of the Jordanian Harrat Aquifer System. Ph.D. Thesis, Technische Universität Darmstadt, Darmstadt, $136 \mathrm{p}$.

[10] Abdulagatova, Z., Abdulagatov, I. and Emirov, V. (2009) Effect of Temperature and Pressure on the Thermal Conductivity of Sandstone. International Journal of Rock Mechanics and Mining Sciences, 46, 1055-1071. https://doi.org/10.1016/j.ijrmms.2009.04.011

[11] Wang, L.W., Tamainot-Telto, Z., Metcalf, S.J., Cristoph, R.E. and Wang, R.Z. (2010) Anisotropic Thermal Conductivity and Permeability of Compacted Expanded Natural Graphite. Applied thermal Engineering, 30, 1805-1811. https://doi.org/10.1016/j.applthermaleng.2010.04.014

[12] El Sayed, A.M.A. (2011) Thermophysical Study of Sandstone Reservoir Rocks. Journal of Petroleum Science and Engineering, 76, 138-147. https://doi.org/10.1016/j.petrol.2011.01.001

[13] Mielke, P., Nehler, M., Bignall, G. and Sass, I. (2015) Thermo-Physical Rock Properties and the Impact of Advancing Hydrothermal Alteration-A Case Study from the Tauhara Geothermal Field, New Zealand. Journal of Volcanology and Geothermal Research, 301, 14-28. https://doi.org/10.1016/j.jvolgeores.2015.04.007

[14] Mielke, P., Weinert, S., Bignall, G. and Sass, I. (2016) Thermo-Physical Rock Properties of Greywacke Basement Rock and Intrusive Lavas from the Taupo Volcanic Zone, New Zealand. Journal of Volcanology and Geothermal Research, 324, 179-189. https://doi.org/10.1016/j.jvolgeores.2016.06.002

[15] Kukkonen, I. and Lindberg, A. (2017) Thermal Properties of Rocks at the Investigation Sites: Measured and Calculated Thermal Conductivity, Specific Heat Capacity, and Thermal Diffusivity. Working Report. https://www.researchgate.net/publication/267364193

[16] Al-Zyoud, S. (2019) Prediction Approach for Petrothermal Properties in Al Hashimiyya Basalts-Jordan. Open Journal of Geology, 9, 43-56.

https://doi.org/10.4236/ojg.2019.91004

[17] Franzson, H., Guðlaugsson, S.P. and Friðleifsson, G. (2001) Petrophysical Properties of Icelandic Rocks. Proceedings of the 6th Nordic Symposium on Petrophysics, Trondheim, 15-16 May 2001, 1-14.

[18] Mielke, P., Bignall, G. and Sass, I. (2010) Permeability and Thermal Conductivity Measurements of near Surface Units at the Wairakei Geothermal Field. World Geothermal Congress, Bali, 25-29 April 2010.

[19] Popov, Y., Pribnow, D., Sass, J., Williams, C. and Burkhardt, H. (1999) Characterization of Rock Thermal Conductivity by High-Resolution Optical Scanning. Geothermics, 28, 253-267. https://doi.org/10.1016/S0375-6505(99)00007-3

[20] Giannakopoulou, P.P., Petrounias, P., Rogkala, A., Tsikouras, B., Stamatis, P.M., Pomonis, P. and Hatzipanagiotou, K. (2018) The Influence of the Mineralogical Composition of Ultramafic Rocks on Their Engineering Performance: A Case Study from the Veria-Naousa and Gerania Ophiolite Complexes (Greece). Geosciences, 8 , 
251. https://doi.org/10.3390/geosciences8070251

[21] Arafin, S. (2019) Thermophysical Properties of Reservoir Rocks. Journal of Physics and Chemistry of Solids, 129, 99-110. https://doi.org/10.1016/j.jpcs.2018.12.034

[22] Vedanti, N., Lakshmi, K.J.P., Dutta, S., Malkoti, A. and Pandey, O.P. (2015) Investigation of Petrophysical Properties and Ultrasonic P- and S-Wave Attenuation in Deccan Flood Basalts, India. SEG Technical Program Expanded Abstracts 2015, 3274-3278. https://doi.org/10.1190/segam2015-5858683.1

[23] Abu Qudaira, M. (2004) The Geology of Zarqa Area, Bulletin 58. Natural Resources Authority, Amman, 47 p.

[24] Al-Malabeh, A. (1993) The Volcanology, Mineralogy and Geochemistry of Selected Pyroclastic Cones from NE-Jordan and Their Evolution for Possible Industrial Applications. PhD Thesis, Erlangen University, Erlangen.

[25] Van den Boom, G. and Sawwan, O. (1966) Report on Geological and Petrological Studies of the Plateau Basalts in NE Jordan. Germ. Geol. Missionin, Amman, 42.

[26] Hunting Technical Services Ltd., Macdonald, S.M. and Partners (1965) Wadi Dhuleil Investigation. Unpubl. Report, Herts, London.

[27] Ilani, S., Harlavan, Y., Tarawneh, K., Rabba, I., Weinberger, R., Ibrahim, K.M., Peltz, S. and Steinitz, G. (2001) New KAr Ages of Basalts from the Harrat Ash Shaam Volcanic Field in Jordan: Implications for the Span and Duration of the Upper Mantle Upwelling beneath the Western Arabian Plate. Geology, 29, 171-174. https://doi.org/10.1130/0091-7613(2001)029<0171:NKAAOB>2.0.CO;2

[28] Al-Zyoud, S. (2005) Mineralogy, Geochemistry and Physico-Mechanical Evaluations of Al-Hashimiyya Basaltic Rocks-Jordan. MSc Thesis, Hashemite University, Jordan.

[29] Goggin, D. (1988) Geologically Sensible Modelling of the Spatial Distribution of Permeability in Eolian Deposity: Page Sandstone (Jurassic), Northern Arizona. University of Texas, Austin, $417 \mathrm{p}$.

[30] Micromeritics (2012) Combining Skeletal and Envelope Volume Measurement. https://www.micromeritics.com/Pressroom/Press-Release-List/Combining-Skeletaland-Envelope-Volume-Measurements-to-Determine-Total-Pore-Volume-and-Perc ent-Porosity.aspx

[31] Brock, E. and Franklin, J.A. (1972) The Point Load Strength Test. International Journal of Rock Mechanics and Mining Sciences \& Geomechanics Abstracts, 9, 669-697.

[32] Humidi, H. (1993) Engineering Properties of Some Selected Basalt Rocks in Northern Jordan. M.Sc. Thesis, Jordan University of Science and Technology, Ramtha, 133.

[33] Touloukian, Y.S., Judd, W.R. and Roy, R.F. (1981) Physical Properties of Rocks and Minerals. McGraw-Hill, New York.

[34] Karakus, A. and Akatay, M. (2013) Determination of Basic Physical and Mechanical Properties of Basaltic Rocks from P-Wave Velocity. Nondestructive Testing and Evaluation, 28, 342-353. https://doi.org/10.1080/10589759.2013.823606

[35] Fortes, A.P.P., Anastasio, S., Kuznetsova, E. and Danielsen, S.W. (2016) Behaviour of Crushed Rock Aggregates Used in Asphalt Surface Layer Exposed to Cold Climate Conditions. Environmental Earth Sciences, 75, 1414. https://doi.org/10.1007/s12665-016-6191-3

[36] Santos, A.R., Veiga, M.R., Santos Silva, A., de Brito, J. and Alvarez, J.I. (2018) Evolution of the Microstructure of Lime Based Mortars and Influence on the Mechani- 
cal Behaviour: The Role of the Aggregates. Construction and Building Materials, 187, 907-922.

[37] Fournari, R. and Ioannis, I. (2019) Correlations between the Properties of Crushed Fine Aggregates. Minerals, 9, 86. https://doi.org/10.3390/min9020086

[38] Bauer, S.J. and Handin, J. (1983) Thermal Expansion and Cracking of Three Confined Water Saturated Igneous Rocks to $800{ }^{\circ} \mathrm{C}$. Rock Mechanics and Rock Engineering, 16, 181-198. https://doi.org/10.1007/BF01033279

[39] Chaki, S., Takarli, M. and Agbodjan, W.P. (2008) Influence of Thermal Damage on Physical Properties of a Granite Rock: Porosity, Permeability and Ultrasonic Wave Evolutions. Construction and Building Materials, 22, 1456-1461. https://doi.org/10.1016/j.conbuildmat.2007.04.002

[40] David, C., Menéndez, B. and Darot, M. (1999) Influence of Stress-Induced and Thermal Cracking on Physical Properties and Microstructure of La Peyratte Granite. International Journal of Rock Mechanics and Mining Sciences, 36, 433-448. https://doi.org/10.1016/S0148-9062(99)00010-8

[41] Fortin, J., Stanchits, S., Vinciguerra, S. and Guéguen, Y. (2011) Influence of Thermal and Mechanical Cracks on Permeability and Elastic Wave Velocities in a Basalt from Mt. Etna Volcano Subjected to Elevated Pressure. Tectonophysics, 503, 60-74. https://doi.org/10.1016/j.tecto.2010.09.028

[42] Homand-Etienne, F. and Houpert, R. (1989) Thermally Induced Microcracking in Granites: Characterization and Analysis. International Journal of Rock Mechanics and Mining Sciences \& Geomechanics Abstracts, 26, 125-134. https://doi.org/10.1016/0148-9062(89)90001-6

[43] Siratovich, P.A., Heap, M.J., Villenueve, M.C., Cole, J.W. and Reuschlé, T. (2014) Physical Property Relationships of the Rotokawa Andesite, a Significant Geothermal Reservoir Rock in the Taupo Volcanic Zone, New Zealand. Geothermal Energy, 2, 313. https://doi.org/10.1186/s40517-014-0010-4

[44] Heap, M.J., Lavallée, Y., Petrakova, L., Baud, P., Reuschlé, T., Varley, N.R. and Dingwell, D.B. (2014) Microstructural Controls on the Physical and Mechanical Properties of Edifice-Forming Andesites at Volcán de Colima, Mexico. Journal of Geophysical Research: Solid Earth, 119, 2925-2963.

https://doi.org/10.1002/2013JB010521

[45] Clauser, C. and Huenges, E. (1995) Thermal Conductivity of Rocks and Minerals. In: Ahrens, T.J., Ed., Rock Physics and Phase Relations-A Handbook of Physical Constants, American Geophysical Union, Washington DC, Vol. 3, 105-126. https://doi.org/10.1029/RF003p0105

[46] Vosteen, H.-D. and Schellschmidt, R. (2003) Influence of Temperature on Thermal Conductivity, Thermal Capacity and Thermal Diffusivity for Different Types of Rock. Physics and Chemistry of the Earth, Parts A/B/C, 28, 499-509. https://doi.org/10.1016/S1474-7065(03)00069-X

[47] Walsh, J.B. and Decker, E.R. (1966) Effect of Pressure and Saturating Fluid on the Thermal Conductivity of Compact Rock. Journal of Geophysical Research, 71, 3053-3061. https://doi.org/10.1029/JZ071i012p03053

[48] Milsch, H.H., Spangenberg, E., Kulenkampff, J. and Meyhöfer, S. (2008) A New Apparatus for Long-Term Petrophysical Investigations on Geothermal Reservoir Rocks at Simulated In-Situ Conditions. Transport in Porous Media, 74, 73-85. https://doi.org/10.1007/s11242-007-9186-4

[49] Pei, L., Rühaak, W., Stegner, J., Bär, K., Homuth, S., Mielk, P. and Sass, I. (2014) Thermo-Triax: An Apparatus for Testing Petrophysical Properties of Rocks under 
Simulated Geothermal Reservoir Conditions. Geotechnical Testing Journal, 38, 20140056. https://doi.org/10.1520/GTJ20140056

[50] Pola, A., Crosta, G., Fusi, N., Barberini, V. and Norini, G. (2012) Influence of Alteration on Physical Properties of Volcanic Rocks. Tectonophysics, 566-567, 67-86. https://doi.org/10.1016/j.tecto.2012.07.017

[51] Wyering, L.D., Villeneuve, M.C., Wallis, I.C., Siratovich, P.A., Kennedy, B.M., Gravley, D.M. and Cant, J.L. (2014) Mechanical and Physical Properties of Hydrothermally Altered Rocks, Taupo Volcanic Zone, New Zealand. Journal of Volcanology and Geothermal Research, 288, 76-93.

https://doi.org/10.1016/j.jvolgeores.2014.10.008

[52] Song, X., Jiang, M. and Xiong, P. (2018) Analysis of the Thermophysical Properties and Influencing Factors of Various Rock Types from the Guizhou Province. E3S Web of Conferences, 53, Article ID: 03059.

https://doi.org/10.1051/e3sconf/20185303059

[53] Mordensky, S., Villeneuve, M., Kennedy, B., Heap, M.J., Gravley, D., Farquharson, J. and Reuschlé, T. (2017) Physical and Mechanical Property Relationships of a Shallow Intrusion and Volcanic Host Rock, Pinnacle Ridge, Mt. Ruapehu, New Zealand. Journal of Volcanology and Geothermal Research, 359, 1-20. 